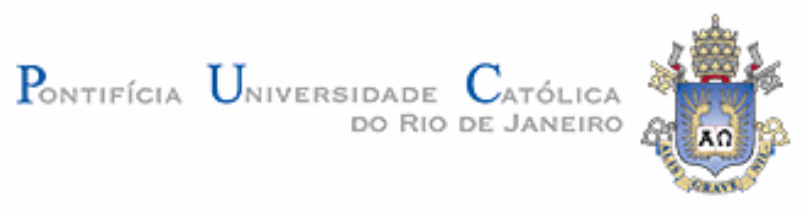

Alexandre Jordão Baptista

\title{
Matemática e Conhecimento na República de Platão
}

\section{Tese de Doutorado}

Tese apresentada ao Programa de Pósgraduação em Filosofia da Puc - Rio como requisito parcial para obtenção do título de doutor em filosofia.

Orientador: Prof ${ }^{a}$ Maura Iglésias

Rio de Janeiro Novembro de 2006 


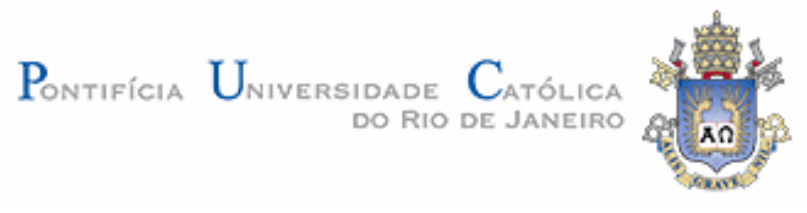

Alexandre Jordão Baptista

"Matemática e conhecimento na República de Platão"

Tese apresentada como requisito parcial para a obtenção do grau de Doutor pelo Programa de Pós-graduação em Filosofia do Centro de Teologia e Ciências Humanas da PUC-Rio. Aprovada pela Comissão Examinadora abaixo assinada.

Profa. Maura Iglésias

Orientadora Departamento de Filosofia da PUC - Rio

Prof. Fernando Augusto da Rocha Rodrigues UFRJ/IFCS

Prof. Fernando Décio Porto Muniz UFF

Prof. Edson Peixoto de Resende Filho Gama Filho

Profa. Maria Inês Sena Anachoreta PUC - Rio

Prof. Paulo Fernando Carneiro de Andrade Coordenador Setorial do Centro de Teologia e de Ciências Humanas - PUC-Rio

Rio de Janeiro, 30 de Novembro de 2006 
Todos os direitos reservados. É proibida a reprodução total ou parcial do trabalho sem autorização da universidade, do autor e do orientador.

\section{Alexandre Jordão Baptista}

Graduou-se em Filosofia na PUC - Rio em 1999. Obteve o título de Mestre em Filosofia na PUC - Rio em 2002. Lecionou Filosofia no Ensino Médio. Participou de diversos congressos de Filosofia no país.

\section{Ficha Catalográfica}

Baptista, Alexandre Jordão

Matemática e conhecimento na República de Platão / Alexandre Jordão Baptista ; orientadora: Maura Iglésias. - 2006.

113 f. ; $30 \mathrm{~cm}$

Tese (Doutorado em Filosofia)-Pontifícia Universidade Católica do Rio de Janeiro, Rio de Janeiro, 2007.

Inclui bibliografia

1. Filosofia - Teses. 2. Filosofia da Matemática. 3. Teoria do Conhecimento. 4. Platão. 5. Dialética. 6. Hipótese. I. Iglesias, Maura. II. Pontifícia Universidade Católica do Rio de Janeiro. Departamento de Filosofia. III. Título.

CDD: 100 


\section{Agradecimentos}

À minha orientadora Profa. Dr. Maura Iglésia, pelas importantes contribuições e palavras de apoio.

Ao CNPq e à PUC - Rio, pelos auxílios concedidos, sem os quais este trabalho não poderia ter sido realizado.

Aos professores que participaram da Comissão examinadora.

Aos professores do Departamento de filosofia da PUC - Rio; aos meus colegas do programa de pós-graduação; e aos funcionários do Departamento, pela ajuda.

A todos os meus amigos, especialmente Ludmila de Andrade e Gledson Teixeira, por todo apoio, paciência e compreensão.

Finalmente, à minha família, especialmente à minha mãe, pelo apoio e carinho, e aos meus irmãos. 


\section{Resumo}

Baptista, Alexandre Jordão; Iglesias Maura. Matemática e Conhecimento na República de Platão. Rio de Janeiro, 2007. 113p. Tese de Doutorado Departamento de Filosofia, Pontifícia Universidade Católica do Rio de Janeiro.

A proximidade entre matemática e filosofia em Platão é algo historicamente estabelecido e que pode ser constatado desde o primeiro contato com a sua obra e com as linhas gerais de seu pensamento. Nesse sentido, encontramos em alguns dos seus principais Diálogos, particularmente em A República, concepções sobre a natureza da matemática relacionadas, sobretudo, à metodologia matemática. $\mathrm{Na}$ República Platão aborda criticamente aspectos referentes ao método e ao status epistemológico das disciplinas matemáticas em dois momentos. O primeiro no Livro VI, na célebre passagem da Linha Dividida (509d - 511e), e o segundo no Livro VII, por ocasião da descrição do programa de estudos preparatórios à dialética (521c-534e) e, em ambos, considerando-se o que Platão diz em outras oportunidades, o teor da crítica platônica surpreende. Na Linha, as disciplinas matemáticas são descritas como formas de conhecimento intermediárias entre a opinião e a dialética, a única a merecer o título de ciência legítima. No Livro VII para ilustrar a distinção entre o conhecimento alcançado pelas disciplinas matemáticas, de um lado, e pela dialética, de outro, é dito que apesar de apreender alguma coisa da essência o matemático estaria para o dialético como aquele que dorme e sonha está para aquele que está acordado e vivendo a realidade (533b 534e). O objetivo desse trabalho, portanto, é investigar por que Platão considera as matemáticas "ciências intermediárias" e qual a noção de "conhecimento" que serve de critério para essa classificação.

\section{Palavras-chave}

Filosofia; Filosofia da Matemática; Teoria do Conhecimento; Platão; Dialética; Hipótese; Método. 


\section{Abstract}

Baptista, Alexandre Jordão; Iglesias Maura. Mathematics and Knowledge in the Plato's Republic. Rio de Janeiro, 2007. 113p. Tese de Doutorado Departamento de Filosofia, Pontifícia Universidade Católica do Rio de Janeiro.

The proximity between mathematics and philosophy in Plato is something historically acknowledged and that can be verified from the first contact with his work and with the general lines of his thought. Thus, one can find in some of his main Dialogues, particularly in the Republic, conceptions on the nature of mathematics mainly related to the mathematical methodology. In the Republic Plato approaches critically aspects regarding the method and the epistemological status of the mathematical disciplines in two moments. The first in Book VI, in the famous fragment of the Divided Line (509d - 511e), and the second in Book VII, while describing the program of preparatory studies to dialectics $(521 \mathrm{c}-534 \mathrm{e})$ and, in both cases, considering what Plato says in other fragments, the character of Plato's criticism surprises. In the Line, the disciplines of mathematics are described as a way of knowledge in-between opinion and dialectics, the last being the only one entitled to be considered a legitimate science. In Book VII, in order to show the distinction between the knowledge reached by mathematical disciplines, on one side, and the dialectics, on another, it is stated that despite learning some of the essence, the mathematician is for the dialectical as one who sleeps and dreams is for those who are awake and living reality itself (533b 534e). Therefore, the aim of this work is to investigate why Plato considers the disciplines of mathematics "in-between sciences" and what notion of "knowledge" was used as the criteria for that classification.

\section{Keywords}

Philosophy; Philosophy of the Mathematics; Theory of the Knowledge; Plato; Dialectics; Hypothesis; Method. 


\section{Sumário}

1. Introdução 8

2. A Linha dividida: Rep. VI 509d-511e 17

3. A crítica de Platão aos matemáticos na Rep. VI 509d-511 27

3.1. A noção de "iтtotí $\theta \epsilon \mu a$ " em Platão 27

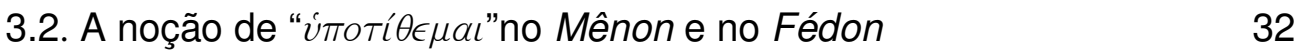

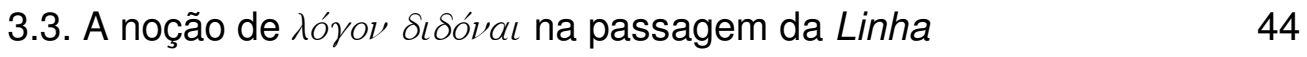

3.4. O uso de imagens sensíveis pelos matemáticos 50

4. Conhecimento na República 56

4.1. A noção de Conhecimento do Livro X (601b - 602b) 56

4.2. República $474 b-480 a$ : a diferença entre aquele que sonha e aquele que está desperto



5.1. A sıávoıa $\quad 71$

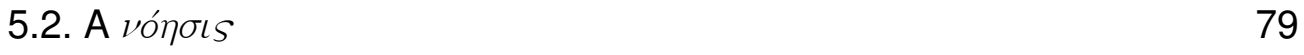

6. Conclusão 105

$\begin{array}{ll}\text { 7. Referências Bibliográficas } & 108\end{array}$ 